University of South Carolina

Scholar Commons

1985

Self-Sufficiency, Cotton, and Economic Development in the South Carolina Upcountry, 1800-1860

Lacy K. Ford, Jr.

University of South Carolina - Columbia, ford@mailbox.sc.edu

Follow this and additional works at: https://scholarcommons.sc.edu/hist_facpub

Part of the History Commons

Publication Info

Published in Journal of Economic History, Volume 45, Issue 2, 1985, pages 261-267.

http://journals.cambridge.org/action/displayJournal?jid=jeh

(C) 1985 by Cambridge University Press

This Article is brought to you by the History, Department of at Scholar Commons. It has been accepted for inclusion in Faculty Publications by an authorized administrator of Scholar Commons. For more information, please contact digres@mailbox.sc.edu. 


\section{Self-Sufficiency, Cotton, and Economic Development in the South Carolina Upcountry, 1800-1860}

LACY K. FORD

The expansion of short-staple cotton production into the southern backcountry during the nineteenth century opened opportunities for backcountry planters and yeomen alike. But contrary to the claims made by agricultural reformers, South Carolina upcountry farmers did not neglect the production of foodstuffs. The Upcountry as a whole was self-sufficient in foodstuffs though a significant minority of farms failed to achieve self-sufficiency. Thus a limited local market in foodstuffs developed, but it did little to stimulate the development of towns in the region.

$\mathbf{R}$

ECENTLY historians, developmental economists, sociologists, and anthropologists have devoted considerable attention to the expansion of commercial agriculture into regions previously isolated from large-scale, market-oriented production. Most of the published studies have shown a special interest in the response of subsistence farmers to market possibilities. In particular, the impact of a strong staple orientation on the production of basic foodstuffs and on the pace of local commerce and town development has been identified as crucial to understanding how the expansion of staple agriculture affects prospects for long-term economic growth. Few regions were transformed more rapidly than the American South during the first half of the nineteenth century. After the British textile revolution and the invention of the cotton gin, the South quickly emerged as the world's largest supplier of short-staple cotton. ${ }^{1}$ Moreover, the rapid expansion of staple agriculture across the South prompted the equally rapid spread of black slavery which influenced the internal development of market relationships in the South. My note examines the expansion of staple agriculture in the South Carolina Upcountry and focuses on how emphasis on cotton production affected the area's self-sufficiency in foodstuffs. ${ }^{2}$

The South Carolina Upcountry played an integral, perhaps even dominant, role in the first short-staple cotton boom of the early

Journal of Economic History, Vol. XLV, No. 2 (June 1985). (C) The Economic History Association. All rights reserved. ISSN 0022-0507.

Lacy K. Ford is Assistant Professor in the Department of History, University of South Carolina, Columbia, South Carolina 29208.

'Gavin Wright, "An Econometric Study of Cotton Production and Trade, 1830-1860," The Review of Economics and Statistics, 53 (May 1971), pp. 111-20.

${ }^{2}$ For a broader investigation see Lacy K. Ford, "Social Origins of a New South Carolina: The Upcountry in the Nineteenth Century"' (Ph.D. dissertation, University of South Carolina, 1983), pp. 1-120, 269-368. I define Upcountry as the portion of the state north and west of the fall line. 
nineteenth century. During the first two decades of the century, cotton production spread rapidly into the lower Piedmont region of South Carolina. Prior to the emergence of cotton as a cash crop, most Piedmont families were part of a subsistence economy which offered little upward mobility or improved living standards. Upcountry farmers generally produced enough food for their own subsistence and sold small grain surpluses in nearby towns, low country plantation districts, or the city of Charleston. Yet as early as the 1790s, the supply of upcountry foodstuffs glutted Charleston and other low country markets. Some upcountry farmers tried tobacco as a cash crop, but low yields, poor quality leaves, and strong outside competition ended dreams of a Piedmont tobacco boom. So, with little market for surplus foodstuffs and no suitable staple crop, Piedmont farmers of the 1790s seemed confined to subsistence agriculture. ${ }^{3}$

The short-staple cotton boom changed the situation. Indeed, the arrival of cotton culture in the Upcountry was hailed as the harbinger of regional economic salvation. Contemporary observers spoke enthusiastically about new avenues of opportunity. As David Ramsey noted during the first boom, cotton could be grown "profitably by individuals or white families without slaves," and, as a result, placed a "new and strong inducement to industry" in the hands of yeomen. "By nice calculation," Ramsey continued, "it appears . . . that the clear profits on one crop planted in cotton will purchase the fee simple of the land. Two, three, or four will in like manner pay for the negroes who make it." Another prominent South Carolinian, Judge William Johnson, noted that before cotton "the whole interior . . . was languishing, and its inhabitants emigrating, for want of some object to engage their attention and employ their industry." The invention of the cotton gin, Johnson claimed, "set the whole country in active motion." According to Johnson, the economic boom triggered by the spread of cotton production could hardly be overstated: "Individuals who were depressed in poverty and sunk in idleness have suddenly risen to wealth and respectability. Our debts have been paid off, our capital increased, and our lands trebled in value.",

Certainly the first boom was impressive in terms of absolute levels of production. In 1793 , the entire state produced only 94,000 pounds of cotton and most of that was the delicate and luxurious long-staple cotton grown primarily on the sea islands around Beaufort. In 1800, the Upcountry alone exported over $6,500,000$ pounds of cotton, all of the short-staple variety. Between 1793 and 1810, the volume of cotton

\footnotetext{
${ }^{3}$ Marjorie S. Mendenhall, "A History of Agriculture in South Carolina, 1790-1860" (Ph.D. dissertation, Univeristy of North Carolina at Chapel Hill, 1940), pp. 93-132.

${ }^{4}$ David Ramsey, The History of South Carolina, 2 vols. (Charleston, S.C., 1809), vol. 2, p. 220.

5 The Federal Cases, Comprising Cases Argued and Determined in the Circuit and District Courts of the United States (St. Paul, Minn., 1894-97), vol. 29, p. 1072.
} 
produced often tripled from one year to the next and by 1810 yearly output for the state reached $50,000,000$ pounds. ${ }^{6}$ Concurring with contemporary commentators, agricultural historian Marjorie Mendenhall credited the cotton boom with "rescuing the small farmer from the doldrums into which many had come since their acquisition of a loghouse and a few score acres." 7

Yet if the first short-staple cotton boom offered the yeomanry an economic alternative, it also bred prodigious ambition among planters. Between 1800 and 1840, substantial landholders parlayed bumper cotton crops into large fortunes. Along the Wateree River, Wade Hampton I, a Virginia native "brought up to labor in the field . . . almost entirely without the advantage of even a common school education," earned $\$ 75,000$ on his first cotton crop in 1799 . By 1810 , Hampton had tripled his slaveholdings and increased his cotton earnings to $\$ 150,000$ a year. John Springs, a large landowner in York district, expanded his slaveholdings and cotton production enough to sport a net worth of over $\$ 100,000$ in 1826. In Union district, Francis F. Gist began working a farm of 400 acres in 1809 and within ten years accumulated over a thousand additional acres, thirty-three slaves, and other personal property valued at just over $\$ 25,000 .^{8}$ In the Upcountry as a whole, slaveowners increased their holdings from 21,000 in 1790 to over 70,000 by 1810 , and the percentage of households owning at least one slave rose from 25 percent to 33 percent during the same interval..$^{9}$

Despite the phenomenal success of some first generation planters, the Upcountry did not turn into a plantation society overnight. In 1810 , only 3 percent of all upcountry households owned enough slaves to merit classification as planters, and 85 percent of all upcountry slaveholders owned fewer than ten slaves. Even as late as 1860 only 5 percent of all household heads were planters, and over half of all slaveholders owned fewer than ten slaves. ${ }^{10}$ From Mark D. Kaplanoff, we know that roughly

\footnotetext{
${ }^{6}$ James Simons, A Rallying Point For All True Friends to Their Country (Charleston, S.C., 1800), pp. 9-19; J. L. Watkins, King Cotton (New York, 1908), pp. 69-93.

${ }^{7}$ Mendenhall, "A History of Agriculture in South Carolina," p. 108.

8 "The Diary of Edward Hooker, 1805-1808," American Historical Association Annual Report, 1896 (Washington, D. C., 1897), vol. 1, p. 846; Whitemarsh B. Seabrook, A Memoir on the Origin, Cultivation and Use of Cotton (Charleston, S.C., 1844), pp. 6-17; Ronald E. Bridwell, "The South's Wealthiest Planter: Wade Hampton I of South Carolina, 1754-1833" (Ph.D. dissertation, University of South Carolina, 1980), pp. 397-504; Katherine Wooten Springs, The Squires of Springfield (Charlotte, N.C., 1965), pp. 16-33; Daniel J. Bell, "Interpretive Booklets for Local Historical Sites: Rose Hill State Park, Union, South Carolina As a Model" (M.A. thesis, University of South Carolina, 1983), pp. 10-17.

${ }^{9}$ These figures were developed from the United States Census, 1790, Heads of Families at the First Census of the United States, South Carolina (Washington, D.C., 1801); United States Census, 1810, Aggregate Amount of Each Description of Persons within the United States (Washington, D.C., 1811); and from the Manuscript Census Schedules for South Carolina for 1790 and 1810 .

${ }^{10}$ Calculations made from United States Census, 1860, Agriculture of the United States in 1860 (Washington, D.C., 1864), p. 237.
} 
half of all the very wealthy upcountry planters who owned over 100 slaves in 1810 had risen from humble or obscure origins. ${ }^{11}$ Most in the region agreed with planter Joseph Jenkins, who hailed cotton as the basis of "all wealth, independence, individual happiness, and respectability." 12 Only a handful saw the staple as a potential source of dependence and stagnation.

By 1840 , however, the relative decline of the Upcountry as a cottonproducing region was a matter of serious concern to state leaders. The region had long been vulnerable to the cyclical booms and busts of the international cotton economy, but the prolonged agricultural depression which followed the Panic of 1837 spurred the state's planter elite to action. Spearheaded by the newly formed State Agricultural Society of South Carolina, a well-organized agricultural reform movement emerged. ${ }^{13}$ Society leaders urged the adoption of scientific farming techniques to combat soil exhaustion and erosion, and chided upcountry farmers for neglecting subsistence crops in favor of cotton. At the second annual meeting of the society in 1840, upcountry planter George McDuffie contended that "It should be an inviolable rule in the economy of every plantation to produce an abundant supply of every species of grain, and of every species of livestock, required for its own consumption." 14 After his statewide agricultural survey in 1842, reformer Edmund Ruffin admonished every planter "to promptly render himself independent in reference to those articles which can be produced on his plantation." 15 The reform crusade, which preached self-sufficiency, had strong political overtones. In the early 1840 s, upcountrymen held to a republican ideology which equated personal independence with liberty. Agricultural reformers saw the lack of selfsufficiency as a serious threat to personal independence. Though subsistence crops should be the first priority of every farmer, cotton profits had induced upcountry farmers to sell cheaply their republican birthright. With this ideological twist, agricultural reformers transformed the drudgery of subsistence to a moral duty of republican citizens.

While agricultural reformers lamented the failure of upcountry farms to achieve self-sufficiency, upcountry farmers claimed that they pro-

${ }^{11}$ Mark D. Kaplanoff, "Making the South Solid: Politics and the Structure of Society in South Carolina, 1790-1815” (Ph.D. dissertation, University of Cambridge, 1979), pp. 22-26.

12 Joseph E. Jenkins, "Address Delivered before the Agricultural Society of St. Johns, Colleton," Southern Agriculturalist, 11 (Aug. 1838), pp. 393-410.

${ }^{13}$ Alfred G. Smith, Economic Readjustment of an Old Cotton State: South Carolina, 1820-1860 (Columbia, S.C., 1958), pp. 19-111.

${ }^{14}$ George McDuffie, "Anniversary Oration of the State Agricultural Society of South Carolina, 26 November, 1840," in The Proceedings of the Agricultural Convention of the State Agricultural Society of South Carolina (Columbia, S.C., 1846), p. 98.

${ }^{15}$ Edmund Ruffin, Report on the Commencement and Progress of the Agricultural Survey of South Carolina for 1843 (Columbia, S.C., 1843), p. 73. 
duced a surplus of foodstuffs which they found difficult, if not impossible, to market. The Milton Agricultural Society, which embraced parts of Laurens and Newberry districts, reported that "we raise among ourselves nearly all the hogs, and all the cattle, that we need for consumption" and that "every farmer raises all the grain which he consumes, and usually markets a surplus of wheat and flour."16 Markets for upcountry grain, however, were spotty. The Fishing Creek Agricultural Society, which included farmers in parts of York and Chester districts, spoke bluntly about the lack of demand for upcountry foodstuffs. "Cotton is our only market produce," the Society reported, "We make our own breadstuffs and would frequently spare large quantities of corn and wheat, but have no regular market for them."17 Such examples of self-sufficient farms and plantations from all parts of the region suggest that the reformers' concerns were overstated.

The ambiguity of the impressionistic evidence concerning southern self-sufficiency has troubled historians just as it confounded South Carolina agricultural leaders during the $1840 \mathrm{~s}$. The weight of recent findings indicates that the Cotton South was essentially self-sufficient in foodstuffs. ${ }^{18}$ Application of the self-sufficiency test developed by Robert Gallman to a sample of upcountry farms revealed that in the aggregate farms in all size groups, except that category of farms with fewer than twenty-five improved acres, achieved self-sufficiency in 1849. In fact, farms with fifty acres and above produced grain surpluses of over 30 percent. When the same self-sufficiency test is applied to farms in the sample on an individual basis, the record of upcountry farms in subsistence production becomes complicated. Small farms found self-sufficiency difficult to achieve. Nearly 40 percent of all farms with fewer than fifty improved acres were not self-sufficient in 1849. In every other size category, an overwhelming majority of all farms achieved self-sufficiency, but a significant minority did not. About 15 percent of all farms with fifty or more improved acres did not raise enough food to satisfy their own requirements. ${ }^{19}$ Even though over 80 percent of all farms produced grain surpluses, a majority of farms failed to produce enough surplus grain to adequately feed their livestock. This finding emphasizes the importance of open-range grazing in the Upcountry. By feeding their swine herds on the range for a portion of the

\footnotetext{
16 "Report of the Committee Appointed by the Milton Agricultural Society," in Edmund Ruffin, Report of the Agricultural Survey: An Appendix (Columbia, S.C., 1843), pp. 8-10.

17 "Report of the Fishing Creek Agricultural Society," in Ruffin, Report of the Agricultural Survey: An Appendix, pp. 5-8.

$\rightarrow$ Robert Gallman, "Self-Sufficiency in the Cotton Economy of the Antebellum South, Agricultural History, 44 (Jan. 1970), pp. 5-23.

${ }^{19}$ One of every ten farms in the districts of Laurens, Spartanburg, and York for the census year 1850 were selected for the sample. Data from the Population, Slave, and Agricultural schedules were then matched and checked. Thus I determined the consumption requirements of each individual household and applied Gallman's self-sufficiency test to individual farms.
} 
TABLE 1

SELF-SUFFICIENCY IN THE SOUTH CAROLINA UPCOUNTRY, 1850

\begin{tabular}{|c|c|c|c|c|}
\hline & \multicolumn{2}{|c|}{ Aggregate } & \multirow{2}{*}{\multicolumn{2}{|c|}{$\begin{array}{c}\text { Individual Farms } \\
\text { Percentage of } \\
\text { Farms Achieving } \\
\text { Self-Sufficiency }\end{array}$}} \\
\hline & \multirow{2}{*}{$\begin{array}{c}\text { Grain Surplus as } \\
\text { Percentage of } \\
\text { Total Grain Output }\end{array}$} & \multirow{2}{*}{$\begin{array}{l}\text { Meat Surplus as } \\
\text { Percentage of } \\
\text { Total Meat Output }\end{array}$} & & \\
\hline & & & Grain & Meat \\
\hline \multicolumn{5}{|c|}{$\begin{array}{l}\text { Farm Size } \\
\quad \text { (improved acres) }\end{array}$} \\
\hline $1-25$ & $-49.9 \%$ & $-55.0 \%$ & $60.0 \%$ & $55.0 \%$ \\
\hline $26-50$ & 17.5 & 41.1 & 59.0 & 80.0 \\
\hline $51-100$ & 36.5 & 45.2 & 87.0 & 85.1 \\
\hline $101-200$ & 38.2 & 41.9 & 86.0 & 82.3 \\
\hline over 200 & 37.0 & 21.9 & 85.0 & 62.0 \\
\hline
\end{tabular}

Source: Manuscript Census of 1850, South Carolina, Laurens, Spartanburg, and York, schedules I, II, and IV.

year, upcountry farmers were able to stretch their grain supply. ${ }^{20}$ (See Table 1.)

Generally, upcountry farmers were successful with subsistence crops, and the data from the 1850 census support the contention of many upcountry farmers and the local agricultural societies that a majority of the region's agriculturalists were self-sufficient. But in a political sense, the fears of the agricultural reformers were wellfounded. Even though the region as a whole produced a surplus of foodstuffs, the existence of a local market in foodstuffs raised traditional republican fears about a loss of independence. Seen through the eyes of republican reformers, a local market, which served as a convenient system for distributing the upcountry food surplus, was transformed into an ominous symbol of declension. ${ }^{21}$

The general self-sufficiency of upcountry farms and the nature of the local market in foodstuffs also had important economic consequences. Quantitative and qualitative evidence suggests that the plantations and large farms produced the surplus food sold in the local market and that buyers tended to be small farmers. Thus small farmers did not have a reliable market for surplus foodstuffs so they depended on cotton as a cash crop. Nearly 80 percent of all farms sampled produced at least some cotton, and over half of all non-slaveholding farmers raised cotton, though often in small amounts. The limited nature of local market activity did little to enhance trade in the widely scattered upcountry towns, and these towns grew very slowly prior to the

${ }^{20}$ I tested for self-sufficiency in meat in two different ways, assuming in one case that swine herds fed on the open range and in the other that swine herds were fed entirely from surplus grain.

${ }^{21}$ Ford, "Social Origins of a New South Carolina," pp. 70-72. 
expansion of railroads into the Upcountry during the $1850 \mathrm{~s} .{ }^{22}$ Selfsufficiency and the resulting weakness of the local market in foodstuffs are partially responsible for the sluggishness of town development in the Upcountry. ${ }^{23}$ Ironically, a key belief in the simple republican creed proved a significant handicap to the Whiggish dreams of town boosters.

$\rightarrow$ Lacy K. Ford, "Rednecks and Merchants: Economic Development and Social Tensions in the South Carolina Upcountry, 1850-1900,' Journal of American History, 71 (Sept. 1984), pp. 294318.

$\rightarrow$ William Parker, "Slavery and Southern Economic Development: An Hypothesis and Some Evidence," Agricultural History, 44 (Jan. 1970), pp. 115-125. 